\title{
Self-Supply Service Level Assessment as Drinking Water Source in Bekasi City (Case Study: Jatiluhur, Sumur Batu, and Jatirangga Villages)
}

\author{
Aprilia Harera ${ }^{1, *}$, Gita Lestari Putri ${ }^{2}$, and Tim Foster ${ }^{3}$ \\ ${ }^{1}$ Civil and Environmental Engineering Department, Faculty of Engineering, Universitas Indonesia, \\ Depok, 16424, Indonesia \\ ${ }^{2}$ Center for Sustainable Infrastructure Development, Universitas Indonesia, Depok, 16424, Indonesia \\ ${ }^{3}$ Institute for Sustainable Futures, University of Technology Sydney, Ultimo, NSW 2007, Australia \\ *Corresponding author: aprilia.harera@ ui.ac.id
}

\begin{abstract}
Drinking water sources derived from groundwater using selfsupply approaches are widely used in Bekasi City because only $26.8 \%$ of households are connected to the piped distribution. These self-supplied water systems can be assessed to determine how people choose a better drinking source. Therefore, this study aims to assess the service level attributes of self-supply, including accessibility, availability, and quality. A longitudinal monitoring method by means of a monthly survey to respondents was used to mens perceptions of taste, smell, color, availability, and safety. The results on both household and citywide scale showed boreholes were perceived to deliver a high service level. On the household scale, $93 \%$ of boreholes user got 'high' score for water service assessment, while dug wells were only $76 \%$. During the 8 months survey, it was shown that $45 \%$ of respondents change their main source of drinking water from self-supply to other source for several reasons. Therefore, this study is expected to provide an overview related to the resilience of selfsupply drinking water for a certain period.
\end{abstract}

\section{Introduction}

According to a report data by the Joint Monitoring Program (JMP) of the United Nations 2019, as many as 1.9 billion people are in need of a safely managed drinking water service including safe, reliable, affordable, and easily accessible drinking water supply that is essential for human health [1]. In fact, Indonesia as a developing country, has not been spared from water and sanitation issues, which has had broad implications for health and development [2]. Therefore it is necessary to improve services in water supply.

Self-supply is a private household supply system through its own investment, and usually relies on low-cost technology [3]. This water service system is an attempt to obtain clean water in households at a low cost, which includes collecting rainwater as well as groundwater sources such as boreholes and dug wells [4]. Currently, half of urban 
households in Indonesia still utilize groundwater [5], and Bekasi City is one of the cities that use this source. Meanwhile, piped water in the city is provided by Regional Drinking Water Company (PDAM), but its coverage is not sufficient. The coverage of the PDAM area currently serves only $26.8 \%$ of the population. Therefore, households that are not connected to piped water use self-supplied groundwater sources for their daily domestic and drinking water needs [6].

Self-supply source can be assess in various aspects including accessibility, availability or quantity, as well as quality. The accessibility aspect is a convenient level, and it is estimated by the duration to reach the water source. Although self-reported water collection times are not always accurate, they provides a useful indicator of the relative time load for water collection [7]. The availability or quantity aspect is the amount of water used by each household and the water available when needed. However, in most cases, it is difficult to calculate, therefore, Sustainable Development Goals (SDGs) are focused on monitoring the duration of water availability $[8,9]$. The quality aspect at the household level usually arises from perceptions, and it is believed that the complex interactions of drinking water factors are associated with quality, which gives a strong influence on quality perceptions. These factors include organoleptic properties (taste, smell, and color), hardness, risk perception, demographics, distrust of suppliers, turbidity, water chemicals, and microbial parameters. This lead to positive and negative perceptions of consumers [10].

Monitoring usage on an ongoing basis could help assess the self-supply service level. Based on the 2020 Indonesia SDGs Environmental Pillar Metadata Report, it fulfills point 6.1.1, which is to ascertain the proportion of households using water services by surveying based on the assumption that the source can provide basic daily needs and meet quality requirements[11]. One of the methods used to monitor reliability and behavior related to the sources is through a water diary [12] or a questionnaire interview method, using a computerized system of Computer Assisted Telephone Interview (CATI) [13]. Regarding current practices, the water diary and the CATI method can be modified according to Bekasi City conditions and considering its limitations. This study used the continuous monitoring survey method, which was carried out in urban areas of developing countries by establishing a more practical approach through short questions and answers to respondents (monthly survey). Therefore, this study aims to determine self-supply service level in Bekasi City by assessing household scale and how the respondent's source of drinking water change over time.

\section{Materials and Methods.}

\subsection{Study Location}

This study was located in three villages in Bekasi City namely Jatiluhur, Sumur Batu, and Jatirangga. Furthermore, it was conducted during dry season (which started in June 2020) and rainy season (started in October 2020). The location was selected based consideration and conditions, such as the population density, high poverty levels, and lack of access to PDAM pipeline services, therefore, most of the population use groundwater as their source. Figure 1 shown the study location in Bekasi City. 

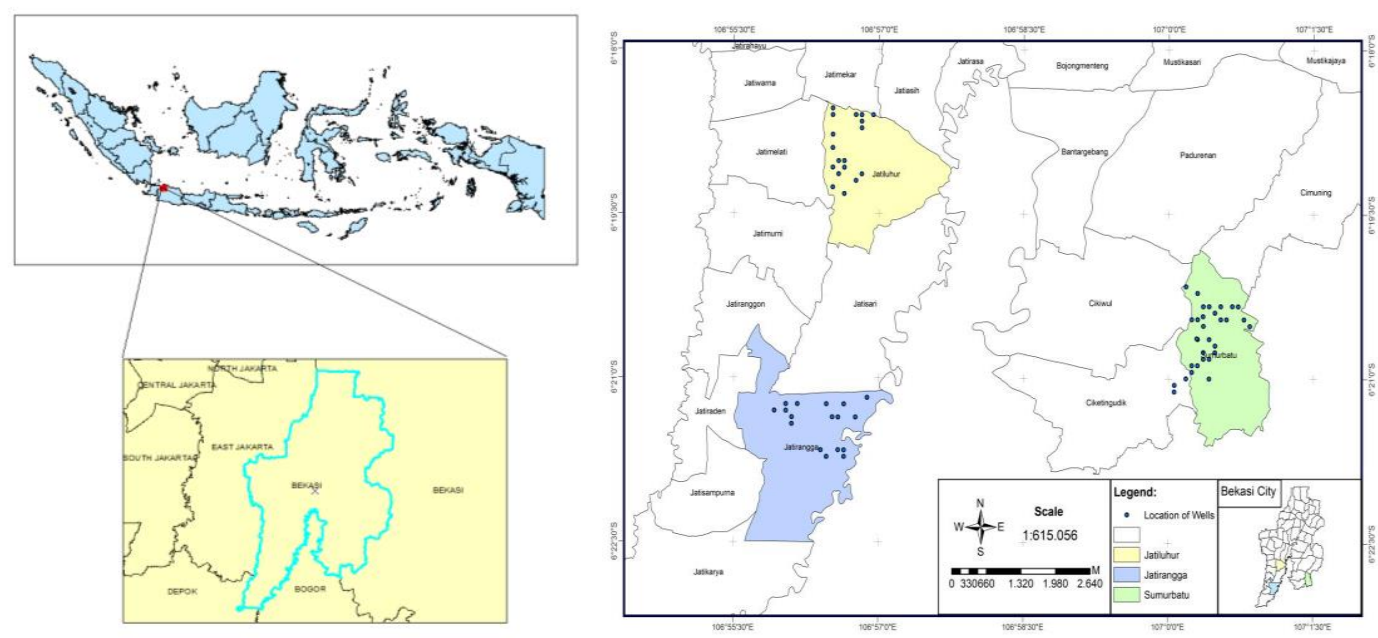

Fig 1. Study Location Map

\section{$2.2 \quad$ Monthly Survey}

The monthly survey method was conducted by telephone and carried out by the enumerator to the respondents who were willing to be interviewed according to existing sample criteria. This study is a follow up from a large survey that had been conducted. In the large survey, respondents were asked about household data, water sources, sanitation, and sampling of water from source and point of use (PoU) [14-17]. Furthermore, the criteria were obtained monthly and prioritized on the respondents whom had taken the PoU sample. The total sample were 89 respondents that obtained based on the respondents' agreement to take the survey via telephone. From total sample, which was about 45 respondents follow the survey from the first month until last month. Also, random sampling was carried out, questions set was made and divided into several parts namely (1) water sources, (2) sanitation and hygiene, (3) economic situation, and (4) health. The interview took approximately 7 to 12 minutes per respondent. During June - September 2020 the writer used Survey Solutions application to interview the respondents, but from October until the end of the study, server could not be accessed due to various problems, subsequently, new application and Qualtrics was used.

\subsection{Data Analysis}

Water service level assessment was conducted in a household scale. These assessments were taken based on five parameter questionnaire namely, the safety, availability, taste, smell, and color derived from respondents' perceptions. The service level concept was adopt from WHO which published in Joint Monitoring Programme (JMP) Report [18]. Safety, taste, color, and smell represent quality, availability represents quantity, while accessibility indicator is not included because it is assumed that most households use directly connected pipes. Meanwhile, each parameter has score 1 if respondent's answer was good and score 0 if respondent's answer wasn't good, and then the score was summed up. A total score of 5 is categorized as high score while $<5$ is lower score. These assessment were based on the author's expert judgment and combine with WHO concept. 


\section{Results and Discussion}

\subsection{Respondent Characteristic}

The related data in Table 1 shows that most of the selected households during monthly surveys in Bekasi City used boreholes as their main source water providing drinking water supplies with an average of $47 \%$, while only approximately $7 \%$ of them chose dug wells. Other than self-supply, the other source of drinking water was mainly refill water. Nearly $26 \%$ of those selected households decided on using refill water for their drinking water supply. Meanwhile, the data obtained from the Central Bureau of Statistics of Bekasi in 2020 indicates that the main source of water in the city was $88.48 \%$ boreholes [18]. As seen in Table 1, the data on the total respondents participating in the survey was fluctuant; there was an increase in the number of respondents by $4 \%$ from June to July. Nevertheless, in the following month, this number decreased by $4 \%$ and became stable for the next month. Subsequently, there was another decrease in this number by $1 \%$ in October and again by another 1\%. From November 2020 to January 2021, the number of respondents remained unchanged. The survey proceeded with a total of 64 respondents. The fluctuation in the number of respondents was due to various factors, e.g. the saturated feeling they experienced during the interview, unavailability of time for interviews, and technical constraints such as respondents' changing telephone numbers. Therefore, the success rate of the data collection depended largely on the trust between enumerators and respondents who were always enthusiastic about participating in the survey[20]. Table 1 also points out that there was a decrease in the number of respondents using boreholes for their drinking water supply, from $47 \%$ to $44 \%$ in the rainy season. Meanwhile, the number of dug well users increased by an average of $15 \%$. Studies found that rainfall variability has a huge impact on water supply where the availability is increasingly fulfilled [20-23].

Table 1. Source of Drinking Water Respondent Characteristic

\begin{tabular}{|c|c|c|c|c|c|c|}
\hline \multirow{3}{*}{ Month } & \multicolumn{6}{|c|}{ Main Source of Drinking Water } \\
\hline & $\begin{array}{l}\text { Dug } \\
\text { Well }\end{array}$ & Borehole & $\begin{array}{l}\text { Artesian } \\
\text { Well }\end{array}$ & $\begin{array}{l}\text { Refill } \\
\text { Water }\end{array}$ & $\begin{array}{l}\text { Bottled } \\
\text { Water }\end{array}$ & \multirow{2}{*}{$\begin{array}{c}\text { Total } \\
\text { (n) }\end{array}$} \\
\hline & $(\%)$ & $(\%)$ & $(\%)$ & $(\%)$ & $(\%)$ & \\
\hline June $2020^{\text {a }}$ & 6 & 47 & 3 & 24 & 19 & 68 \\
\hline July $2020^{a}$ & 5 & 47 & 1 & 32 & 14 & 74 \\
\hline August $2020^{a}$ & 6 & 47 & 3 & 29 & 15 & 68 \\
\hline$\underset{\mathbf{a}}{\text { September } 2020}$ & 6 & 47 & 3 & 29 & 15 & 68 \\
\hline October $2020^{b}$ & 6 & 45 & 6 & 26 & 17 & 66 \\
\hline $\begin{array}{l}\text { November } \\
2020^{\mathbf{b}}\end{array}$ & 8 & 42 & 3 & 28 & 19 & 64 \\
\hline $\begin{array}{l}\text { December } \\
2020^{\mathbf{b}}\end{array}$ & 8 & 48 & 3 & 22 & 19 & 64 \\
\hline January $2021^{\mathbf{b}}$ & 9 & 41 & 3 & 22 & 17 & 64 \\
\hline Mean & 7 & 46 & 3 & 28 & 17 & 67 \\
\hline Std. Deviation & 1,3 & 2,5 & 1,3 & 3,1 & 1,9 & 3,1 \\
\hline
\end{tabular}

\footnotetext{
${ }^{*} \mathrm{a}=$ Dry Season $; \mathrm{b}=$ Wet Season
} 


\subsection{Self-Supply as Drinking Water Service Level Asssessment}

Figure 2 shows a household scale graph based on self-supply sources (e.g. unprotected private wells and private boreholes) with service level parameters being smell, taste, color, safety, and availability. The histogram presents the result of the survey conducted in each household for eight months. As seen in the histogram, after calculating all parameters, a borehole has a higher score than a dug well, despite having problems in the taste, smell, color, and availability indicators.

During the survey period (June 2020 - January 2021), the dry season started from June to September, while the rainy season was from October to January. Boreholes had the lowest score in November compared to any other months; $12 \%$ of the respondents reported it as not good. It was the rainy season in November, and $98 \%$ of the respondents informed that rain fell for 24 hours before the interview. Meanwhile, the dug wells assessment result showed that $100 \%$ of the respondents considered the drinking water service level at its highest score in September and November. As for the average assessment result for boreholes in the dry season, $92 \%$ of them got high score, while dug wells were at $75 \%$. In the rainy season, boreholes increased to $93 \%$, while dug wells decreased to $73 \%$. The percentage of dug well users was lower in the rainy season than in the dry season, while boreholes was higher in the rainy seasons.

From the result above, it can be analyzed that rain might affect the water infiltration into the soil and could also dissolve various chemicals and contaminants that cause the taste and smell of water. This has an impact on the assessment of drinking water service level. In addition, the taste and smell parameters have been highlighted as key factors influencing the acceptance of drinking water by respondents[23]. However, the perception of drinking water has been based on varying scientific paradigms with different conceptual and methodological approaches[10]. Annual and seasonal rainfall variability significantly affects water supply in terms of both quality and availability. Critical problems in accessing safely managed drinking water, e.g. the availability, access, and control of water usage, always occur during the dry season. In the meantime, in the rainy season, it depends on the amount of rainfall which will have an impact on water availability [7-8]. Similar studies revealed that unprotected dug wells scored higher in the dry season than in the rainy season in terms of water quality, usage satisfaction, reliability, and adequacy [26]. A research by Maysarah, et. al [16] found that dug wells, specifically unprotected ones in urban villages, were easily contaminated. The results of the microbial contamination testing by checking the quality of $E$. coli contamination showed that only $31 \%$ of the boreholes were contaminated with E. coli, whereas the percentage reached $44 \%$ for the dug wells. A similar result was obtained in this research, where dug wells got lower scores than boreholes, although it was solely based on respondents' perceptions. Unfortunately, to date, there are insufficient studies to figure out the perception's assessment of drinking water from boreholes and dug wells. 


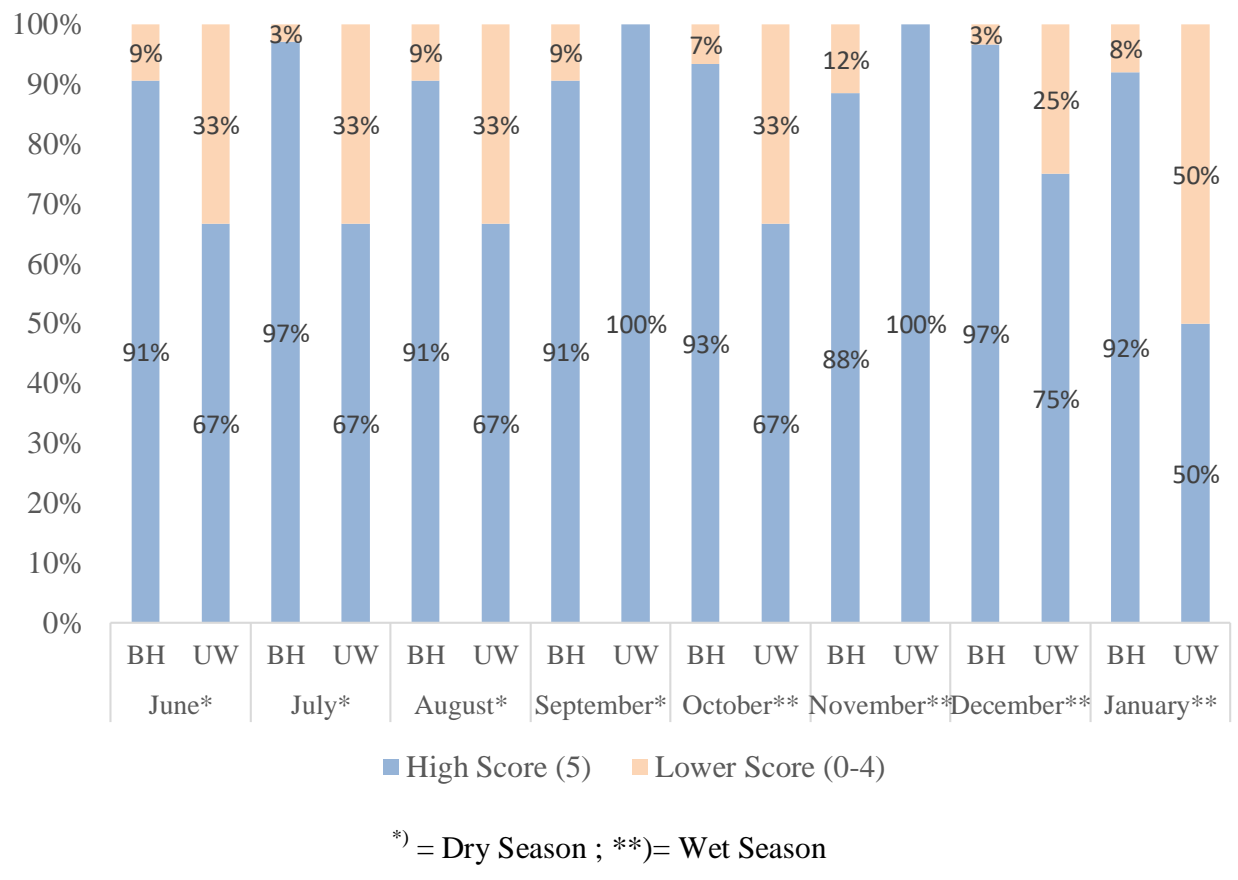

Fig. 2. Household Scale Service Level Asssessment based on Self-Supply of Drinking Water

\subsection{Change in Drinking Water Sources}

The survey of water consumption for each respondent had changed in line with the appearing problems with the primary drinking water source. Figure 3 shows that within the period of eight months, some respondents changed their main source of drinking water from self-supply to another source or vice versa. The data shown in the diagram were respondents who had participated in the survey for at least 3 months. Approximately $45 \%$ of the households shifted from self-supply to other sources, such as refill water or branded gallon, or vice versa. On the other hand, around $55 \%$ of the respondents consistently used self-supply water sources. In another study, it was found that the majority of households used the same source throughout the year, with only about $2.6 \%$ of them altered their source of water [27].

Reasons for changing preferences were recorded through monthly survey interviews, namely (1) different seasons, (2) damaged well infrastructure, (3) lack of water availability, (4) economic downturn. The number of those changing their preferences was close to half the total respondents.

A similar reason was found in another research that there was a strong relationship between the change of seasons and the change in preferences for main drinking water sources. This depended on the water service assessment, including water quality and water quantity [29-30]. Mitigation was carried out by the respondents before entering a different season. Based on a large-scale survey in Bekasi [14], 37\% of the borehole respondents and $39 \%$ of the dug well respondents had repaired their wells due to damaged well infrastructure. They switched to another source of drinking water that was easily accessible while waiting for the well to be repaired. The increase and decrease in annual rainfall affects the availability of drinking water [30]. During the dry season, wells might dry out so 
that the availability of water decreases. This makes respondents change their primary drinking water supply to other sources. From the same previous research about drinking water preferences, it was found that there was a statistically significant relationship between drinking water preference and economic condition [31]. It proved that the reason the respondents changed their primary source of drinking water was based on economic downturn. They prefered to choose the cheapest one, possibly from branded gallons to unprotected wells.

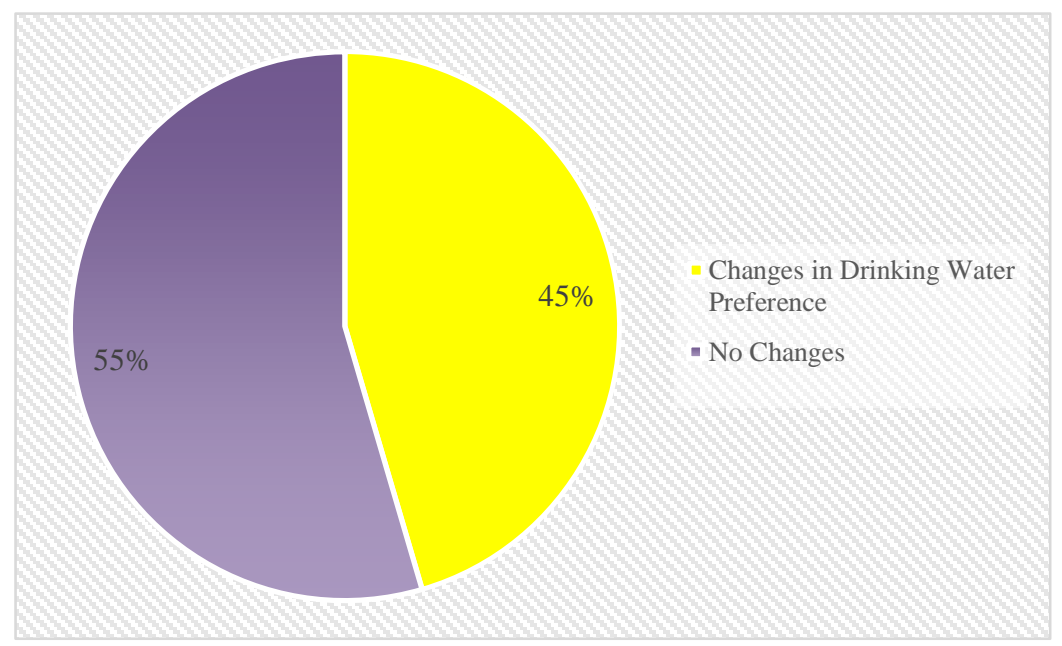

Fig. 3. Change of Self-Supply Drinking Water Sources in Households for the Period of June-January 2021

\section{Conclusion}

Overall, users' interest in dug wells increases by an average of $15 \%$ at the beginning of the rainy season. In addition, through an assessment on a household scale, it is found that boreholes have a higher service level than dug wells. The household scale observing at the service level assessment of the respondent's water sources found that $92 \%$ of the boreholes received high scores, while there was only $76 \%$ for the dug wells. Seasonal variability has an effect on dug wells, where they have lower score in the rainy season than in the dry season, vice versa with boreholes. However, about $45 \%$ of the respondents changed their source of drinking water because they felt there was a problem with their drinking water, so they took precautionary measures to drink safer water. Therefore, boreholes perceived to deliver a high service level through public perception. This is strengthened by the results of the microbial contamination testing through checking the quality for $E$. coli contamination, showing that only $31 \%$ of the boreholes were contaminated with E. coli, compared to the dug wells which stood at $44 \%$.

Improvement and maintenance are needed, as well as raising awareness about safely managed water among the Bekasi City community regarding self-supply sources of drinking water. Future studies should consider the background of the respondents expressing their perceptions of water sources and monthly water quality testing to validate those perceptions. 
This research was funded by the Water for Women Fund from Australian Government Department of Foreign and Trade with number WRA1:1004 and the conference was funded by PTUPT from Indonesian Ministry of Research and Technology with contract number NKB277/UN2.RST/HKP.05.00/2021 and also collaborative PPKI program from the Indonesian World Class University Research Scheme. We thank Dr. Cindy Rianti Priadi, from Universitas Indonesia as thesis supervisor for supporting, suggesting, and giving an opportunity to conduct this research, Prof. Juliet Willetts from ISF- University of Technology Sydney for imparting her knowledge and expertise in this study, Franziska Genter from ISF-University of Technology Sydney for her sincere guidance and invaluable help for completing this research, and also Dr. Angela Harris from NC State University for giving some advice and ideas to accomplish this research paper.

\section{References}

1. WHO, National System to Support Drinking Water, Sanitation, and Hygiene: Global Status Report 2019. (2019)

2. T. Afifah, M. T. Nuryetty, Cahyorini, D. A. Musadad, A. Schlotheuber, N. Bergen, and R. Johnston, Glob. Health Action 11, (2018)

3. $\quad$ M. F. MacCarthy, J. E. Annis, and J. R. Mihelcic, Water Altern. 6, 424 (2013)

4. $\quad$ S. Sutton, Increm. Improv. Priv. Invest. Rural Water Supply 1 (2009)

5. I. M. Setiono, J. Woodcock, B. Djumhana, R. Sukarma, and B. Parton, Indonesia Water Investment Roadmap 2011-2014 (2012)

6. Bappeda Kota Bekasi, Rencana Pembangunan Jangka Menengah Daerah Kota Bekasi 20182023 (Bekasi, 2018)

7. S. Adelana, A. Tamiru, D. Nkhuwa, C. Tindimugaya, and M. Oga, in Appl. Groundw. Stud. Africa, (Taylor \& Francis, 2008), pp. 231-260

8. WHO and UNICEF, 1 (2017)

9. A. R. Dianjaya and P. Epira, J. Contemp. Gov. Public Policy 1, 27 (2020)

10. M. F. Doria, J. Water Health 4, 271 (2006)

11. Bappenas, Pilar Pembangunan Lingkungan (2020)

12. K. Harriden, J. Water Sanit. Hyg. Dev. 3, 70 (2013)

13. J. E. O'Toole, M. I. Sinclair, and K. Leder, BMC Med. Res. Methodol. 9, 1 (2009)

14. I. Imtiyaz, G. L. Putri, D. M. Hartono, F. Zulkarnain, and C. R. Priadi, IOP Conf. Ser. Earth Environ. Sci. 633, (2021)

15. T. Rahmawati, G. L. Putri, D. R. Marthanty, F. Zulkarnain, and C. R. Priadi, IOP Conf. Ser. Earth Environ. Sci. 633, (2021)

16. S. Maysarah, G. L. Putri, M. A. Pratama, F. Zulkarnain, J. Willetts, T. Foster, F. Genter, A. Harris, and C. R. Priadil, IOP Conf. Ser. Earth Environ. Sci. 566, (2020)

17. W. H. Pratiwi, G. L. Putri, M. A. Pratama, F. Zulkarnain, and C. R. Priadi, IOP Conf. Ser. Earth Environ. Sci. 633, (2021)

18. P. Moriarty, C. Batchelor, C. Fonseca, A. Klutse, A. Naafs, K. Nyarko, C. Pezon, A. Potter, V. R. Reddy, and M. Snehalatha, IRC - Int. Water Sanit. Cent. 24 (2011)

19. Badan Pusat Statistik, 634 (2020)

20. V. Wiseman, L. Conteh, and F. Matovu, Health Policy Plan. 20, 394 (2005)

21. V. Srinivasan, S. M. Gorelick, and L. Goulder, Water Resour. Res. 46, 1 (2010)

22. British Columbia Ground Water Association, Water Steward. Inf. Ser. (2007)

23. M. R. Francis, G. Nagarajan, R. Sarkar, V. R. Mohan, G. Kang, and V. Balraj, BMC Public Health 15, 0 (2015)

24. R. C. Calow, A. M. MacDonald, A. L. Nicol, and N. S. Robins, Ground Water 48, 246 (2010)

25. K. Tussupova, P. Hjorth, and R. Berndtsson, Int. J. Environ. Res. Public Health 13, (2016)

26. J. Butterworth, S. Sutton, and L. Mekonta, Water Altern. 6, 405 (2013)

27. K. H. Nguyen, D. J. Operario, M. E. Nyathi, C. L. Hill, J. A. Smith, R. L. Guerrant, A. Samie, R. A. Dillingham, P. O. Bessong, and E. T. Rogawski McQuade, Int. J. Hyg. Environ. Health 231, 113640 (2021)

28. S. Twisa and M. F. Buchroithner, Water (Switzerland) 11, (2019) 
29. H. T. M. Nguyen, Q. T. P. Le, J. Garnier, J. L. Janeau, and E. Rochelle-Newall, Sci. Rep. 6, 1 (2016)

30. J. M. Melillo, T. C. Richmond, G. W. Yohe, and U. S. G. P. Office, U.S. Glob. Chang. Res. Progr. 148 (2014)

31. R. Aydin and S. Sirin, Desalin. Water Treat. 175, 329 (2020) 